\title{
FAKTOR RISIKO KEJADIAN GIZI BURUK DI KABUPATEN LOMBOK TIMUR, PROPINSI NUSA TENGGARA BARAT
}

\author{
Khaerul Anwar', M. Juffrie ${ }^{2}$, Madarina Julia ${ }^{2}$
}

\begin{abstract}
Background: Despite numerous interventions, the prevalence of severe malnutrition in under fives in the District of Lombok Timur during the last 5 years did not changed much and tended to increase.

Objective: To assess risk factors for severe malnutrition, considered from points of view of family characteristics, children rearing practice and performance of posyandu, in 12 to 23 month-infants in the district.

Methods: This was a case-control study. Cases were 65 severely malnourished children, while controls were a same number of children matched for age.

Results: In bivariate analyses, variables identified as risk factors of severe malnutrition are low family income, $O R(95 \% C l)$ of 5.0 (1.9-13.5), $p=0.001$; low maternal education, $O R(95 \% \mathrm{Cl})$ of $2.3(1.1-4.9), p=0.02$; low maternal knowledge on growth monitoring, OR(95\% Cl) of 15.6 (4.4-55.1), $p<0.001$; not cared by mother, OR(95\% Cl) of $7.8(1.7-36.5)$, $p=0.003$; low birth weight, OR(95\%Cl) of $5.7(1.2-27.3)$, $p=0.02$; short duration of exclusive breastfeeding, OR $(95 \% \mathrm{Cl})$ of 2.6 (1.3-5.2), $p=0.008$; incomplete immunization, OR $(95 \% \mathrm{Cl})$ of 10.3 (2.3-46.9), $p<0.001$; and the children's feeding practice, $\mathrm{OR}(95 \% \mathrm{Cl})$ of $3.3(1.5-7.4), p=0.004$. In multiple logistic regression, only maternal knowledge on growth monitoring was significantly associated with the risk of severe malnutrition.

Conclusion: Family characteristic and children rearing practice were important risk factors of severe malnutrition in Lombok Timur District. Performance of posyandu is not associated with occurrence of severe malnutrition.
\end{abstract}

Key words : Severe malnutrition, performance of Posyandu, family characteristic, children rearing practice.

\section{PENDAHULUAN}

Tantangan utama dalam pembangunan suatu bangsa adalah membangun sumber daya manusia yang berkualitas, sehat, cerdas dan produktif. Pencapaian pembangunan manusia yang diukur dengan Indeks Pembangunan Manusia (IPM) dalam tiga dasawarsa terakhir belum menunjukkan hasil yang menggembirakan. Pada tahun 2003, IPM Indonesia masih rendah, yaitu berada pada peringkat 112 dari 174 negara, lebih rendah dari negara-negara tetangga. Rendahnya IPM ini sangat dipengaruhi oleh rendahnya status gizi dan status kesehatan penduduk (1).
Data SUSENAS tahun 2003 menunjukkan bahwa prevalensi gizi buruk di NTB sebesar 10,43\%, sedangkan gizi kurang $23,8 \%$ (2). Pada bulan Mei dan Juni 2005, dilaporkan penemuan kasus busung lapar (honger oedema) atau marasmik-kwashiorkor di beberapa propinsi, termasuk NTB. Sampai akhir Desember 2005 tercatat 3950 kasus gizi buruk (BB/TB), 40 orang di antaranya meninggal dunia (3).

Lombok Timur adalah salah satu kabupaten di Propinsi NTB dengan jumlah kasus gizi buruk terbanyak. Selama 5 tahun terakhir, prevalensi gizi buruk di Lombok Timur tidak banyak berubah. Hasil Pemantauan Status Gizi (PSG) menggambarkan prevalensi gizi buruk yang cenderung meningkat, yaitu: $3,84 \%$ (2001), 5,04\% (2002), 3,79\% (2003), 3,50\% (2004) dan 6,41\% (2005). Pada bulan Desember 2005 di Kabupaten Lombok Timur dilaksanakan kegiatan pekan penimbangan. Pada kegiatan tersebut ditemukan 3011 kasus gizi buruk, 109 orang di antaranya menunjukkan tanda-tanda klinis seperti marasmus, kwashiorkor dan marasmik-kwashiorkor (4).

Berdasarkan gambaran di atas serta model penyebab gizi buruk yang dikembangkan UNICEF, peneliti tertarik untuk mempelajari faktor-faktor risiko yang berpengaruh terhadap kejadian gizi buruk di Kabupaten Lombok Timur. Faktor risiko yang diteliti adalah faktor yang terkait dengan faktor karakteristik keluarga, pola asuh anak, dan kinerja posyandu.

\section{BAHAN DAN METODE}

\section{Rancangan dan Subjek Penelitian}

Penelitian ini adalah penelitian analitik dengan rancangan kasus kontrol. Kasus adalah anak usia 1223 bulan dengan gizi buruk, sedangkan kontrol adalah anak dengan kelompok umur yang sama tanpa gizi buruk (gizi baik). Kasus dan kontrol diambil dari anak balita usia 12-23 bulan yang mengikuti pekan penimbangan pada bulan Desember 2005.

Pekan penimbangan pada Desember 2005 mengukur 95.084 anak balita, 491 anak di antaranya

\footnotetext{
1 Dinas Kesehatan Propinsi Nusa Tenggara Barat

2 Bagian Anak RS Dr. Sardjito/Fakultas Kedokteran UGM, Yogyakarta
} 
tergolong gizi buruk. Dari 491 anak tersebut, 109 anak menunjukkan tanda-tanda klinis gizi buruk. Sebanyak 65 kasus diambil dari 109 anak tersebut, yaitu yang berusia 12-23 bulan. Kontrol sebanyak 65 anak bergizi baik berasal dari wilayah puskesmas yang sama dengan kasus.

\section{Variabel Penelitian}

Variabel penelitian meliputi variabel terikat gizi buruk, yaitu status gizi kurang dari -3 SD indeks berat badan terhadap tinggi badan atau panjang badan menurut standar WHO-CDC 2000 yang disertai dengan tanda klinis gizi buruk. Variabel bebas terdiri dari 16 variabel yang terkait dengan aspek karakteristik keluarga, pola asuh anak dan kinerja posyandu. Ke16 variabel tersebut adalah: urutan anak, rasio anak yang hidup, jumlah balita dalam keluarga, jumlah anggota keluarga, status sosial ekonomi, umur ibu, tingkat pendidikan ibu, status kawin ibu, pengetahuan ibu mengenai pemantauan pertumbuhan, pengasuh anak, berat badan lahir, lama ASI eksklusif, status menyusui, status imunisasi anak, pola makan anak dan kinerja posyandu.

Urutan anak adalah nomor urutan (posisi) anak balita yang dilahirkan dari satu ibu dalam 1 keluarga. Sedangkan rasio anak yang hidup adalah perbandingan (rasio) antara jumlah anak yang hidup dengan jumlah anak yang dilahirkan oleh ibu balita.

Jumlah balita dalam keluarga adalah jumlah anak umur 0-59 bulan yang ada dalam satu keluarga. Sedangkan jumlah anggota keluarga adalah jumlah semua anggota keluarga yang menjadi tanggungan kepala keluarga. Yang dimaksud satu keluarga adalah semua anggota keluarga yang menjadi tanggungan kepala keluarga, tinggal satu atap dan makan dari satu dapur.

Status sosial ekonomi keluarga adalah keadaan keluarga yang tergambar dari aspek pendapatan keluarga, keadaan rumah tinggal dan kepemilikan barang. Pendapatan keluarga dikelompokkan menjadi 2: "cukup" ( $\geq$ mean) dan "kurang" (< mean). Keadaan rumah dikelompokkan menjadi 2: "baik" (skor 6-9) dan "kurang" (skor 0-5). Kepemilikan barang dikelompokkan menjadi 2: "baik" (skor 22-45) dan "kurang" (skor 0-21).

Umur ibu adalah umur biologis yang dicapai ibu pada saat wawancara dilakukan. Umur yang diambil adalah umur penuh atau berdasarkan ulang tahun terakhir. Sedangkan tingkat pendidikan ibu adalah lama pendidikan formal dalam tahun (SD, SMP, SMA, termasuk MI, MTs, MA) yang ditempuh ibu. Status kawin adalah status perkawinan ibu, apakah masih berstatus kawin atau istri secara sah (hukum) dari seorang suami, atau sudah janda (cerai hidup atau mati).

Pengetahuan ibu mengenai pemantauan pertumbuhan adalah pengetahuan ibu mengenai kegiatan pemantauan pertumbuhan yang mencakup 3 hal: trend berat badan, posisi berat badan dan frekuensi pemantauan. Skor pengetahuan ibu didasarkan pada jawaban ibu terhadap 5 buah kasus plotting berat badan pada KMS menggunakan format test KMS.

Berat badan lahir adalah berat badan anak ketika lahir (baik prematur maupun cukup bulan). Skala pengukuran nominal: "normal" ( $\geq 2500 \mathrm{~g}$ ) dan "rendah" (<2500 g). Sedangkan status imunisasi anak adalah kelengkapan jenis imunisasi yang diterima anak (sesuai jadwal). Status menyusui adalah keadaan pemberian ASI kepada anak balita saat wawancara.

Pengasuh anak adalah orang yang berperan paling dominan dalam pengasuhan anak (memasak makanan, memberi makan, memandikan, melindungi, membantu mencari pengobatan jika sakit). Lama ASI eksklusif adalah rentang waktu (dalam bulan) pemberian ASI secara eksklusif (tidak ada makanan atau minuman lain) yang dialami anak balita. Pola makan anak adalah tindakan ibu dalam hal memberikan makan anak balita termasuk perilaku pemberian ASI. Variabel ini dirinci dalam 4 faktor: ASI eksklusif, status menyusui saat ini, bentuk makanan, dan banyaknya makan. Ke-4 faktor diberi skor 0-25.

Kinerja posyandu adalah proses dan hasil (output) yang dicapai posyandu, dalam menyediakan jasa pelayanan kepada masyarakat $(5,6)$. Dalam penelitian ini kinerja posyandu diukur dengan 2 aspek, yaitu: proses dan output pelayanan di posyandu. Proses pelayanan mencakup: rata-rata cakupan posyandu (K/S); rata-rata tingkat partisipasi /kehadiran sasaran di posyandu (D/ S); rata-rata hasil kegiatan penimbangan di posyandu, atau rasio jumlah balita yang naik berat badannya dibandingkan jumlah balita yang datang ke posyandu (N/D-O-B); frekuensi kehadiran di posyandu adalah jumlah (kali) kedatangan ibu atau balita ke posyandu untuk mengikuti kegiatan pemantauan pertumbuhan (D); serta rata-rata rujukan kasus serta penyuluhan di posyandu, semuanya dalam 1 tahun terakhir (12 bulan, Januari-Desember 2005). Ouput pelayanan di posyandu dinilai dengan rata-rata jumlah gangguan pertumbuhan balita: jumlah balita yang berturut-turut 3 kali tidak naik berat badannya (3T); dan rasio jumlah balita yang berat badannya di Bawah Garis Merah dibandingkan dengan jumlah balita ditimbang (BGM/D) per bulan selama 1 tahun terakhir. 


\section{Pengumpulan dan Analisis Data}

Pengumpulan data dilakukan oleh peneliti dibantu 17 orang tenaga enumerator alumni Politeknik Kesehatan Jurusan Gizi Mataram yang sedang magang di puskesmas lokasi penelitian. Data terutama dikumpulkan dengan mengunjungi rumah sasaran dan dilakukan wawancara dengan kuesioner. Pengambilan data mengenai kegiatan posyandu dilakukan dengan observasi dan pencatatan dari register di posyandu.

Data dientri dan dianalisis dengan program analisis data statistik. Dilaporkan rasio odds (=OR, odds ratio) serta interval kepercayaan 95\% (IK 95\%) atas berbagai faktor risiko gizi buruk antara kasus dan kontrol. Analisis regresi logistik berganda digunakan untuk menilai pengaruh berbagai variabel secara bersamaan.

\section{HASIL DAN BAHASAN}

Subjek penelitian berasal dari 21 wilayah puskesmas dari 26 puskesmas yang sudah mengirimkan laporan pekan penimbangan. Subjek anak lakilaki sedikit lebih banyak dibandingkan perempuan. Berdasarkan urutan anak, sebagian besar subjek penelitian merupakan anak ke-1 dan ke-2 (64,9\%), sisanya merupakan anak ke-3 dan seterusnya. Pada penelitian ini dianalisis 16 variabel dari 3 faktor risiko yang dikaji, yaitu faktor karakteristik keluarga, pola asuh anak dan kinerja posyandu.

Pada Tabel 1 dapat dilihat 8 variabel, dari 15 variabel yang dinilai, yang menunjukkan perbedaan bermakna antara kasus dan kontrol. Untuk faktor risiko yang berhubungan dengan kinerja posyandu, dapat dilihat bahwa tidak ada perbedaan risiko prevalen antara berbagai kinerja posyandu yang dinilai (Tabel 2).

Selanjutnya untuk mengetahui besar pengaruh setiap variabel secara interaktif dilakukan uji regresi berganda. Variabel yang diuji adalah variabel yang memiliki kemaknaan cukup kuat $(p<0,05)$ serta diduga memiliki kontribusi penting bagi kejadian gizi buruk (Tabel 3).

Tabel 3 menunjukkan ada 5 variabel menunjukkan hubungan yang secara statistik bermakna $(p<0,05)$; yaitu: pengetahuan ibu mengenai pemantauan pertumbuhan $(\mathrm{OR}=8,1)$, status imunisasi $(\mathrm{OR}=3,9)$, berat badan lahir $(\mathrm{OR}=3,8)$, pengasuh anak $(\mathrm{OR}=3,7)$, dan pendapatan keluarga $(\mathrm{OR}=2,4)$. Namun dari 5 variabel tersebut, 4 variabel (status imunisasi, berat badan lahir, pengasuh anak dan pendapatan keluarga) memiliki nilai interval kepercayaan (IK $95 \%$ ) mencakup angka 1, artinya belum dapat disimpulkan bahwa ke-4 variabel tersebut merupakan faktor risiko atau faktor protektif. Sedangkan variabel pengetahuan ibu mengenai pemantauan pertumbuhan terbukti bermakna sebagai faktor risiko kejadian gizi buruk di Kabupaten Lombok Timur.

\section{Karakteristik Keluarga dan Gizi Buruk}

Dari beberapa variabel yang terkait dengan karakteristik keluarga, karakteristik ibu dan anak, ada 5 variabel secara sendiri-sendiri yang menunjukkan perbedaan bermakna atau berisiko terhadap kejadian gizi buruk, yaitu tingkat pendidikan ibu, pendapatan keluarga per bulan, pengetahuan ibu mengenai pemantauan pertumbuhan, status imunisasi anak dan berat badan lahir anak. Tetapi ketika dilakukan uji multivariat (analisis simultan) hanya variabel pengetahuan ibu yang menunjukkan kebermaknaan atau berisiko terhadap kejadian gizi buruk.

Anak balita yang dilahirkan oleh seorang ibu dengan pendidikan formal kurang dari 9 tahun berisiko 2,3 kali menjadi gizi buruk. Pendidikan dasar 9 tahun adalah target pemerintah dalam program wajib belajar. Dengan demikian, keberhasilan program wajib belajar dapat mengurangi risiko anak-anak balita terkena gizi buruk di masa mendatang.

Dalam penelitian ini rata-rata lama sekolah ibu pada kelompok kasus adalah 5,8 tahun atau SD tidak tamat, sedangkan pada kelompok pembanding (gizi baik) 8,3 tahun atau setara SMP kelas 3 . Faktor pendidikan terkait erat dengan pola asuh anak, terutama anak yang masih diasuh oleh ibunya.

Penelitian ini menunjukkan bahwa pengetahuan ibu yang kurang mengenai pemantauan pertumbuhan memberikan risiko tertinggi bagi terjadinya gizi buruk. Secara sendiri, variabel ini memberi risiko 15,6 kali dan secara bersama-sama memberi risiko 8,1 kali. Pengetahuan yang baik berkontribusi terhadap perilaku pemberian makan dan juga upaya deteksi dini gizi buruk.

Ibu yang memahami dengan baik pentingnya pemantauan pertumbuhan, akan tetap datang ke posyandu meskipun umur anak sudah melewati jadwal imunisasi. Kehadiran ibu di posyandu secara rutin dapat mencegah seorang anak menjadi gizi buruk, karena proses menjadi gizi buruk - yang diperkirakan 2-3 bulan - dapat dideteksi secara dini melalui kegiatan penimbangan di posyandu. Dalam penelitian ini angka kehadiran ibu ke posyandu dalam 1 tahun terakhir sangat tinggi (rata-rata 10 kali) dan relatif sama, antara kasus maupun kontrol. Frekuensi kehadiran yang tinggi ini seharusnya memberikan dampak yang baik terhadap pengetahuan ibu mengenai KMS. Diperlukan waktu sampai 9 bulan ( 9 kali kunjungan) bagi seorang ibu untuk memahami dengan baik kurva pertumbuhan (7).

Setelah dilakukan wawancara kepada ibu balita gizi buruk, sebagian besar $(95,4 \%)$ tidak mengerti pemantauan pertumbuhan dengan baik. Kondisi ini berbeda bermakna dengan ibu-ibu balita gizi baik, hanya $56,9 \%$ yang tidak mengerti. 
TABEL 1. Faktor risiko kejadian gizi buruk

\begin{tabular}{|c|c|c|c|c|c|}
\hline \multirow{2}{*}{ Faktor risiko } & \multicolumn{2}{|c|}{ Jumlah } & \multirow{2}{*}{$\begin{array}{l}\text { Rasio } \\
\text { odds }\end{array}$} & \multirow{2}{*}{ IK $95 \%$} & \multirow{2}{*}{$\mathbf{p}$} \\
\hline & Kasus & Kontrol & & & \\
\hline \multicolumn{6}{|l|}{ Urutan anak: } \\
\hline Anak ke-2 dan seterusnya & 45 & 39 & 1,5 & $0,7-3,1$ & 0,27 \\
\hline Anak pertama & 20 & 26 & 1,0 & & \\
\hline \multicolumn{6}{|l|}{ Jumlah balita dalam keluarga: } \\
\hline$>1$ orang & 14 & 6 & 0,6 & $0,2-1,5$ & 0,25 \\
\hline 1 orang & 51 & 59 & 1,0 & & \\
\hline \multicolumn{6}{|l|}{$\begin{array}{l}\text { Rasio anak hidup terhadap anak } \\
\text { yang dilahirkan : }\end{array}$} \\
\hline$<100 \%$ & 14 & 8 & 2,0 & $0,8-5,0$ & 0,16 \\
\hline $100 \%$ & 51 & 57 & 1,0 & & \\
\hline \multicolumn{6}{|l|}{ Jumlah anggota keluarga: } \\
\hline$>4$ orang & 32 & 28 & 0,8 & $0,4-1,6$ & 0,48 \\
\hline$\leq 4$ orang & 33 & 37 & 1,0 & & \\
\hline \multicolumn{6}{|l|}{$\begin{array}{l}\text { Status sosial ekonomi keluarga: } \\
\text { Pendapatan keluarga/bulan }\end{array}$} \\
\hline$<$ Rp. $313577,-$ b & 59 & 43 & 5,0 & $1,9-13,5$ & $0,001^{*}$ \\
\hline \multirow{2}{*}{\multicolumn{6}{|c|}{$\begin{array}{l}\quad \geq \text { Rp. } 313 \text { 577,-- } \\
\text { Keadaan rumah : }\end{array}$}} \\
\hline & & & & & \\
\hline Skor $0-5$ & 18 & 9 & 2,4 & $1,0-5,8$ & 0,05 \\
\hline Skor 6-9 & 47 & 56 & 1,0 & & \\
\hline \multicolumn{6}{|l|}{ Kepemilikan barang : } \\
\hline Skor $0-21$ & 63 & 60 & 2,62 & $0,5-14,0$ & 0,24 \\
\hline Skor $22-45$ & 2 & 5 & 1,0 & & \\
\hline \multicolumn{6}{|l|}{ Umur ibu } \\
\hline Berisiko ( $<19$ atau $>35$ tahun) & 14 & 9 & 1,7 & $0,7-4,3$ & 0,25 \\
\hline Tidak berisiko ( $20-35$ tahun) & 51 & 56 & 1,0 & & \\
\hline \multicolumn{6}{|l|}{ Tingkat pendidikan ibu } \\
\hline$<9$ tahun & 49 & 37 & 2,3 & $1,1-4,9$ & $0,02^{*}$ \\
\hline$\geq 9$ tahun & 16 & 28 & 1,0 & & \\
\hline \multicolumn{6}{|l|}{ Status kawin ibu } \\
\hline Janda/pisah & 7 & 5 & 1,5 & $0,4-4,8$ & 0,54 \\
\hline Kawin & 58 & 60 & 1,0 & & \\
\hline \multicolumn{6}{|l|}{$\begin{array}{l}\text { Pengetahuan ibu mengenai } \\
\text { pemantauan pertumbuhan }\end{array}$} \\
\hline Kurang (Skor: 0-40) & 62 & 37 & 15,6 & $4,4-55,1$ & $<0,001^{*}$ \\
\hline Cukup (Skor: 41-100) & 3 & 28 & 1,0 & & \\
\hline \multicolumn{6}{|l|}{ Pengasuh anak } \\
\hline Bukan ibu balita & 13 & 2 & 7,8 & $1,7-36,5$ & $0,003^{*}$ \\
\hline Ibu balita & 52 & 63 & 1,0 & & \\
\hline \multicolumn{6}{|l|}{ Berat badan lahir } \\
\hline$<2500$ gram & 10 & 2 & 5,73 & $1,2-27,3$ & $0,02^{*}$ \\
\hline$\geq 2500$ gram & 55 & 63 & & & \\
\hline \multicolumn{6}{|l|}{ Lama ASI eksklusif } \\
\hline$<4$ bulan & 38 & 23 & 2,57 & $1,3-5,2$ & $0,008^{*}$ \\
\hline$\geq 4$ bulan & 27 & 42 & 1,0 & & \\
\hline \multicolumn{6}{|l|}{ Status menyusui } \\
\hline Tidak menyusui & 27 & 17 & 2,0 & $1,0-4,2$ & 0,06 \\
\hline Menyusui & 38 & 48 & 1,0 & & \\
\hline Status imunisasi & & & & & \\
\hline Tidak lengkap & 16 & 2 & 10,3 & $2,3-46,9$ & $<0,001^{*}$ \\
\hline Lengkap & 49 & 63 & 1,0 & & \\
\hline Pola makan anak & & & & & \\
\hline Kurang baik $($ Skor < 60) & 26 & 11 & 3,27 & $1,5-7,4$ & $0,004^{*}$ \\
\hline Baik (Skor $\geq 60$ ) & 39 & 54 & 1,0 & & \\
\hline
\end{tabular}

Keterangan:

* Signifikan $(p<0,05)$

a Interval kepercayaan 95\%

b Mean pendapatan keluarga 
TABEL 2. Hubungan faktor kinerja Posyandu dengan kejadian gizi buruk

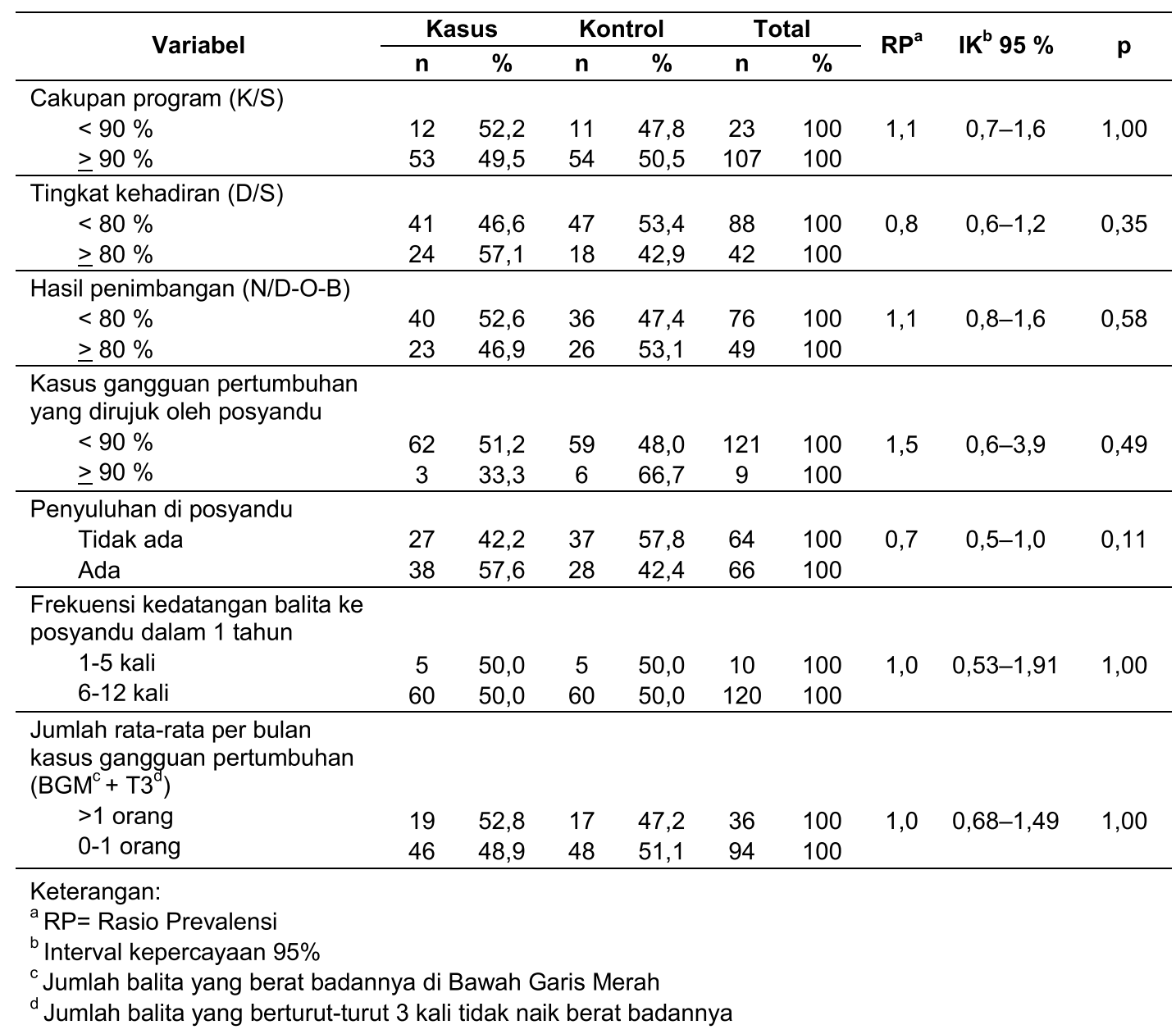

Pemantauan pertumbuhan yang dirancang sebagai media penyuluhan dan pendidikan gizi dinilai belum berjalan baik (8). Indikasinya adalah munculnya kasus gizi buruk di berbagai daerah termasuk NTB, yang seharusnya bisa dicegah jika proses pemantauan pertumbuhan di posyandu berjalan baik. Salah satu kritik terhadap kegiatan ini adalah ketidak-mampuannya memberikan pemahaman kepada sasaran mengenai growth charts/KMS (9). Hal ini disebabkan oleh lemahnya metode dan operasional pelaksanaan penyuluhan di posyandu. Jika ditelaah data kinerja posyandu, 50,8\% responden mengaku mendapat penyuluhan di Posyandu, walaupun jumlah responden yang mendapat materi penyuluhan yang menyangkut pemantauan pertumbuhan/ KMS hanya 2 orang ( $3 \%$ dari semua materi penyuluhan).

Proses penyuluhan di posyandu didukung oleh adanya media penyuluhan. Dalam penelitian ini $33,8 \%$ posyandu memiliki sarana/media penyuluhan. Namun dengan angka kunjungan posyandu (D/S) yang cukup tinggi (rata-rata $63,5 \%$ ) dan biasanya mereka datang secara berkelompok, maka diperkirakan proses penyuluhan/konseling mengenai KMS atau pertumbuhan balita menjadi tidak efektif.

Perilaku pemberian makan tidak hanya didorong oleh sikap yang positif atau pengetahuan gizi yang baik, tetapi juga terkait dengan pendapatan keluarga. Pendapatan keluarga adalah faktor utama dalam kelompok sosial ekonomi. Dalam penelitian ini, keluarga dengan pendapatan kurang dari Rp313.577,00 per bulan (mean penghasilan keluarga) berisiko munculnya gizi buruk 5,0 kali lebih besar bila dibandingkan dengan keluarga dengan pendapatan lebih atau sama dengan Rp313.577,00 per bulan.

Rata-rata pendapatan per bulan pada keluarga gizi buruk Rp218.307,00 atau sekitar Rp7.250,00 per hari. Angka ini berbeda cukup besar (signifikan) dengan pendapatan keluarga gizi baik yaitu Rp408.846,00 per bulan atau sekitar Rp13.650,00 per hari. Namun kedua kelompok pendapatan ini masih di bawah Upah Minimum Regional (UMR) Kabupaten Lombok Timur yang sebesar Rp450.000,00 per bulan. 
TABEL 3. Analisis logistik berganda faktor risiko kejadian gizi buruk

\begin{tabular}{lccc}
\hline \multicolumn{1}{c}{ Faktor yang berpengaruh } & $\begin{array}{c}\text { Rasio } \\
\text { odds }\end{array}$ & IK $\mathbf{~ 9 5 ~}^{\text {\% }}$ & p \\
\hline $\begin{array}{l}\text { Rasio anak yang hidup terhadap anak yang dilahirkan } \\
\text { (<100\%) }\end{array}$ & 1,6 & $0,48-5,37$ & 0,44 \\
Status sosial ekonomi keluarga: & & & \\
$\quad$ Pendapatan keluarga/bulan (<Rp. 313 577) b & 2,4 & $0,6-10,4$ & $0,02^{*}$ \\
$\quad$ Keadaan rumah (skor 0-5) & 1,4 & $0,4-4,2$ & 0,59 \\
$\quad$ Kepemilikan barang (skor 0-21) & 1,4 & $0,1-12,3$ & 0,78 \\
Tingkat pendidikan ibu (<9 tahun) & 1,4 & $0,5-4,0$ & 0,51 \\
Pengetahuan ibu mengenai pemantauan pertumbuhan (skor & 8,1 & $2,0-33,3$ & $0,004^{*}$ \\
0-40) & & & $0,01^{*}$ \\
Pengasuh anak (bukan ibunya) & 3,7 & $0,6-23,3$ & $0,01^{*}$ \\
Berat badan lahir (<2500 gram) & 3,8 & $0,7-20,8$ & 0,4 \\
Lama ASI eksklusif (<4 bulan) & 1,6 & $0,5-4,9$ & 0,62 \\
Tidak menyusui & 0,7 & $0,2-2,7$ & $0,01^{*}$ \\
Status imunisasi tidak lengkap & 3,9 & $0,7-22,2$ & 0,50 \\
Pola makan anak (skor <60) & 1,8 & $0,3-9,1$ & \\
\hline Keterangan: & & & \\
* Signifikan (p<0,05) & & &
\end{tabular}

Dengan pendapatan serendah itu (Rp7.250,00 per hari), keluarga gizi buruk tentu kesulitan dalam mengatur keuangan rumah tangga, terutama dalam pemenuhan gizi balita. Sumber daya yang terbatas ini diperberat lagi dengan jumlah rata-rata anggota keluarga (1 dapur) sebesar 4,9 orang dan 1,3 orang balita per keluarga. Akibatnya alokasi distribusi makanan dalam keluarga menjadi kecil.

Faktor distribusi makanan dalam keluarga sebagai salah satu penyebab kurang energi protein, selain kemiskinan dan penyapihan yang tidak tepat (9). Analisis data SUSENAS menunjukkan dari total pendapatan orang miskin, 70-72\% digunakan untuk pengeluaran pangan (11).

Pendapatan yang kurang, sebenarnya dapat ditutupi jika keluarga tersebut mampu mengolah sumber daya yang terbatas, antara lain dengan kemampuan memilih bahan makanan yang murah tetapi bergizi dan distribusi makanan yang merata dalam keluarga. Dalam pemenuhan jumlah dan mutu konsumsi gizi dalam keluarga, alokasi makanan hampir selalu didasarkan pada status hubungan antaranggota keluarga, bukan atas pertimbangan gizi (12). Misalnya, mendahulukan bapak selaku kepala keluarga dalam hal makan, baik jenis makanan (lauk) maupun jumlah, baru kemudian diikuti ibu dan anak. Penelitian di Kecamatan Sakra Barat, Lombok Timur, menemukan bahwa 53,3\% responden mengutamakan bapak dalam pemberian makan, diikuti anak usia 0-6 tahun $(36,7 \%)(13)$.
Selain faktor pendapatan, pengetahuan ibu dan tingkat pendidikan ibu; status imunisasi yang tidak lengkap juga memberi risiko yang tinggi, yaitu 10,3 kali secara sendiri-sendiri. Secara simultan dalam analisis multivariat, variabel status imunisasi tidak menunjukkan kebermaknaan atau berisiko terhadap gizi buruk.

Status imunisasi merupakan faktor yang berhubungan dengan kejadian infeksi, khususnya infeksi penyakit-penyakit yang dapat dicegah imunisasi. Pada penelitian ini tidak ditelusuri secara spesifik jenis penyakit yang diderita balita, sehingga tidak dapat disimpulkan bahwa penyakit yang diderita balita terkait dengan tidak lengkapnya imunisasi.

Status imunisasi yang tidak lengkap mungkin terkait dengan kontak yang tidak lengkap sampel terhadap kegiatan posyandu, karena imunisasi sebagian besar dilakukan di posyandu. Tingginya risiko menjadi gizi buruk pada anak yang tidak lengkap imunisasinya mungkin terkait dengan pelayanan posyandu yang tidak lengkap diterima anak balita.

Variabel berat badan lahir juga turut berpengaruh bagi terjadinya gizi buruk. Pada penelitian ini risiko menjadi gizi buruk 5,7 kali (secara sendiri) dan 3,8 kali (secara bersama-sama) lebih tinggi pada balita yang mempunyai berat badan lahir rendah (kurang dari 2500 gram). Rata-rata berat badan lahir dari anak yang gizi buruk 2763,8 gram, sedangkan yang gizi baik 3219,2 gram. Ada perbedaan sebesar 455,4 gram, dan perbedaan ini bermakna pada tingkat kepercayaan $95 \%$. 
Proporsi kasus yang memiliki berat badan lahir rendah (kurang dari 2500 gram) sebesar $15,4 \%$, dan pada kontrol $3,1 \%$. Angka-angka ini menunjukkan bahwa potensi gangguan pertumbuhan lebih banyak dialami oleh kelompok gizi buruk dibandingkan gizi baik. Karena, seperti diketahui, dampak BBLR adalah meningkatnya risiko kesakitan (morbiditas) dan gangguan pertumbuhan fisik ketika memasuki umur balita. Kematian akibat BBLR mencapai $2 / 3$ dari seluruh kematian neonatal yaitu yang meninggal pada usia kurang dari 28 hari.

Secara umum, menurut hasil Pemantauan Wilayah Setempat (PWS) KIA, persentase kasus BBLR di Kabupaten Lombok Timur sepanjang 2004 sebesar $2,83 \%$, lebih tinggi dari angka NTB, 2,67\%. Hal ini menunjukkan bahwa Kabupaten Lombok Timur mempunyai potensi menghasilkan gizi buruk lebih besar dibandingkan rata-rata kabupaten/kota se-NTB (14).

\section{Pola Asuh Anak dan Gizi Buruk}

Karakteristik pola asuh diwakili oleh beberapa variabel. Ada 3 variabel yang secara parsial berisiko terhadap kejadian gizi buruk, yaitu pengasuh anak, pola makan anak dan lama pemberian ASI eksklusif. Anak yang diasuh bukan oleh ibunya berisiko menjadi gizi buruk 7,9 kali, namun secara multivariat risiko itu menjadi tidak bermakna.

Khusus di pulau Lombok, Propinsi NTB, faktor pengasuh anak ini sudah lama diduga sebagai penyebab gizi buruk. Hal ini dikaitkan dengan ditemukannya gizi buruk pada keluarga yang ditinggal suami menjadi TKI dan istri menjadi TKW, sementara anak diasuh oleh neneknya atau anggota keluarga yang lain. Secara ekonomi mungkin mereka mencukupi, tetapi pengasuhan yang tidak dilakukan oleh ibunya sendiri diduga berisiko bagi timbulnya gizi buruk. Penelitian di pulau Lombok tahun 2002 menunjukkan bahwa anak yang diasuh bukan oleh ibunya memiliki risiko 2,85 kali menjadi gizi buruk. Dalam penelitian ini, $80 \%$ anak balita pada kelompok gizi buruk diasuh oleh ibunya sendiri, sedangkan pada gizi baik persentasenya lebih besar, yaitu $97 \%$. Pada analisis stratifikasi, faktor pengasuh anak merupakan perancu hubungan pendapatan dengan gizi buruk. Artinya kejadian gizi buruk pada keluarga dengan pendapatan di atas rata-rata, dipengaruhi oleh faktor pengasuh anak (15).

Selain pengasuh anak, faktor pola makan juga menentukan kejadian gizi buruk. Pola makan anak yang kurang baik secara sendiri-sendiri memberikan risiko 3,3 kali, namun secara bersama dengan variabel lain tidak menunjukkan kebermaknaan, atau tidak berisiko terhadap kejadian gizi buruk.

Durasi atau lama pemberian ASI eksklusif yang kurang dari 4 bulan berisiko 2,57 kali bagi terjadinya gizi buruk. Tetapi ketika berinteraksi dengan variabel lain, variabel ini tidak bermakna sebagai faktor risiko. Lutter mengutip Butte et al (16) mengemukakan bahwa bayi yang menyusui secara eksklusif pada lingkungan yang optimal akan tumbuh lebih besar dibanding standar NCHS pada usia 3 bulan pertama. Pada penelitian ini proporsi ASI eksklusif (eksklusif 4 bulan) pada kelompok kasus sebesar $41,5 \%$, dan pada kontrol $64,6 \%$. Rentang waktu pemberian ASI secara eksklusif pada kelompok kasus (gizi buruk) adalah 2,6 bulan, sedangkan pada gizi baik 3,5 bulan. Perbedaan ini secara statistik bermakna.

Pemberian ASI secara eksklusif (4 bulan) merupakan perilaku yang sulit ditingkatkan. Di NTB, angka ASI eksklusif 4 bulan tercatat kurang dari $40 \%$ (17). Pemberian ASI secara tidak eksklusif di NTB, khususnya di pulau Lombok, dipicu oleh rendahnya pengetahuan ibu-ibu dan keluarga mengenai ASI.

Sementara itu, sebanyak $41,5 \%$ balita gizi buruk tidak menyusui lagi, dengan alasan yang tidak digali dalam penelitian ini. Sedangkan pada kelompok gizi baik, proporsi yang tidak menyusui sebesar $26,2 \%$. Dengan demikian, balita gizi buruk lebih banyak yang tidak mendapat cukup ASI dibandingkan gizi baik di usia 12 23 bulan. Meskipun marasmus dapat terjadi pada semua kelompok umur, tetapi kejadian ini lebih banyak ditemukan pada bayi atau anak yang tidak cukup mendapat ASI dan tidak mendapatkan makanan yang berkualitas baik sebagai penggantinya (18).

Pemberian ASI yang tidak optimal 2 tahun ini diperkirakan akibat pengetahuan yang kurang dan adanya program pemberian makanan pendamping ASI (MP-ASI) yang gencar diberikan sepanjang tahun 2005. Pola pemberian ASI dan makanan bayi juga lebih banyak ditentukan oleh nenek bayi. Kebiasaan pemberian makanan prelakteal dan makanan padat dini masih dijumpai pada sebagian besar pengunjung posyandu.

\section{Kinerja Posyandu dan Gizi Buruk}

Selain faktor karakteristik keluarga dan pola asuh anak, faktor kinerja posyandu juga dikaji dalam kaitannya dengan kejadian gizi buruk. Namun dari beberapa variabel kinerja posyandu, tidak ada yang menunjukkan korelasi bermakna dengan terjadinya gizi buruk.

Penilaian kinerja menyangkut 2 hal, yaitu penilaian proses dan output atau keluaran (5). Dalam penelitian ini, proses yang dinilai adalah proses pelayanan di posyandu, yang tercermin dari indikator pelayanan seperti cakupan program (K/S), partisipasi masyarakat dalam pelayanan posyandu (D/S), hasil pelayanan di posyandu (N/D-O-B), jumlah kasus gangguan pertumbuhan yang dirujuk dan proses penyuluhan di 
posyandu. Sedangkan keluaran yang dinilai adalah indikator jumlah kasus gangguan pertumbuhan yang terjadi setiap bulan.

Sepanjang tahun 2005, cakupan balita yang terdaftar di posyandu (K/S) Kabupaten Lombok Timur sebesar $94,6 \%$, angka kunjungan balita (D/S) $63,1 \%$, dan hasil penimbangan (N/D-O-B) $72,3 \%$. Data ini menunjukkan bahwa meskipun hampir semua balita $(94,6 \%)$ telah terdaftar di setiap posyandu, namun yang datang sekitar $60 \%$. Artinya ada sekitar $40 \%$ balita yang kondisinya tidak termonitor oleh posyandu. Balita yang tidak datang ini berpotensi untuk menjadi gizi buruk.

Jika dilihat data kunjungan subjek penelitian ke posyandu, angkanya cukup tinggi. Rata-rata 10-11 kali dalam setahun mereka datang ke posyandu, baik kasus maupun pembanding. Tingginya frekuensi kunjungan ini, khususnya pada ibu balita gizi buruk, ternyata tidak mencegah anak menjadi gizi buruk. Mungkin ada faktor lain yang menyebabkannya, seperti proses deteksi dini melalui penimbangan di posyandu yang kurang baik. Akibatnya anak yang rajin datang menimbang tetap menjadi gizi buruk. Kader atau pengelola posyandu tidak mampu mendeteksi dengan baik proses menjadi gizi buruk tersebut. Hal ini mungkin terkait adalah ketiadaan intervensi atau follow up terhadap anak yang terdeteksi gizi buruk.

Kinerja posyandu tidak terkait langsung dengan kejadian gizi buruk. Kinerja posyandu yang baik seharusnya berpengaruh terhadap proses deteksi dini kejadian gizi buruk, selain meningkatnya pengetahuan ibu mengenai gizi dan kesehatan. Dalam penelitian ini, meskipun kinerja posyandu antara kedua subjek penelitian relatif sama, namun ada perbedaan yang bermakna pada pengetahuan ibu mengenai pemantauan pertumbuhan. Hal ini mungkin disebabkan oleh faktor lain di luar kinerja posyandu, seperti tingkat pendidikan ibu. Meskipun posyandu yang dikunjungi sama-sama memberikan penyuluhan gizi, tetapi daya serap pengunjung (ibu balita) terhadap materi penyuluhan yang diberikan tidak sama, dan ini mungkin dipengaruhi oleh tingkat pendidikan.

\section{KESIMPULAN DAN SARAN}

Dari 3 faktor yang diteliti, karakteristik keluarga dan pola asuh anak teridentifikasi sebagai faktor risiko kejadian gizi buruk di Kabupaten Lombok Timur. Faktor kinerja posyandu tidak berkorelasi dengan kejadian gizi buruk.

Ada 8 variabel yang secara parsial (sendiri-sendiri) berpengaruh terhadap kejadian gizi buruk di Kabupaten Lombok Timur, yaitu: tingkat pendapatan keluarga, tingkat pendidikan ibu, pengetahuan ibu mengenai pemantauan pertumbuhan, pengasuh anak, berat badan lahir, lama ASI eksklusif, status imunisasi dan pola makan anak.
Sedangkan secara bersama-sama (simultan), hanya variabel pengetahuan ibu mengenai pemantauan pertumbuhan yang berpengaruh bermakna terhadap kejadian gizi buruk di Kabupaten Lombok Timur.

Dalam jangka pendek di lingkup kesehatan (internal), perlu dibenahi keterpaduan program antara program gizi dengan KIA dan antara program gizi dengan imunisasi. Keterpaduan KIA-Gizi diarahkan untuk meningkatkan status gizi ibu hamil sehingga akan melahirkan bayi yang tidak BBLR. Selain itu, keterlibatan bidan yang lebih intensif dalam program gizi diharapkan dapat meningkatkan durasi ASI eksklusif, perbaikan pola makan anak, serta meningkatkan pengetahuan ibu mengenai pemantauan pertumbuhan.

Fungsi posyandu sebagai sarana pendidikan gizi kepada ibu diharapkan meningkat, antara lain dengan memperbaiki metode penyuluhan gizi yang selama ini belum berjalan baik, diikuti juga dengan peningkatan pengetahuan dan keterampilan kader.

Dalam jangka menengah atau panjang secara lintas sektoral, perlu dipikirkan program peningkatan pendapatan khususnya kepada keluarga miskin atau keluarga gizi buruk. Model pemberian modal usaha harus diimbangi dengan pembimbingan, sehingga keluarga yang serba kekurangan itu bisa berusaha sambil belajar. Di samping itu perlu juga ditingkatkan pendidikan ibu-ibu balita, misalnya dengan program Kejar Paket $A$ yang diperkaya dengan pendidikan gizi.

\section{RUJUKAN}

1. Azwar A. Kecenderungan Masalah Gizi dan Tantangan di Masa Datang. Pertemuan Advokasi Program Perbaikan Gizi Menuju Keluarga Sadar Gizi: 2004; Jakarta, Indonesia.

2. Depkes RI. Kasus Gizi Buruk di Propinsi Nusa Tenggara Barat. Depkes RI; 2005 b. Available: http:/ /www.gizi.net. Cited 2005 June 29.

3. Dikes LOTIM. Laporan Sementara Hasil Pekan Penimbangan Kabupaten Lombok Timur (Up Dated 30 Juni 2005). Selong: Dinas Kesehatan Lombok Timur; 2005.

4. Dikes NTB. Laporan Hasil Pemantauan Status Gizi (PSG) Balita Propinsi NTB Tahun 2005. Mataram: Dinas Kesehatan Propinsi NTB; 2005

5. Anker M, and Guidotti R. Rapid Evaluation Methods of Health Services Performance. Bulletin on World Health Organization 1993;71:15-16.

6. Ilyas Y. Kinerja, Teori, Penilaian dan Penelitian. Jakarta: Pusat Kajian Ekonomi Kesehatan, FKM UI; 2002.

7. Morley DC. Mothers Monitor Growth. Tropical Doctor July 1993;98-100, In: Lancet 08/23/97 Vol. 350 Issue 9077, p562, 2p, 1 chart 
8. Ruel MT. Growth Monitoring as an Educational Tool, an Integrating Strategy, and a Source of Information: a Review of Experience. In: Pinstrup-Andersen P, Pelletier D, Alderman H, editors. Child Growth and Nutrition in Developing Countries. London: Cornell University Press; 1995. p. 78 - 96.

9. UNICEF. The State of The World's Children 2002. New York: UNICEF. In: Food and Nutrition Bulletin 2003;24(4).

10. Latham MC. Protein Energy Malnutrition. In: Brown $\mathrm{ML}$, editors. Present Knowledge in Nutrition. 6th ed. Washington DC: ILSI Press; 1990.

11. Atmarita. Analisis Ketahanan Pangan Tingkat Rumah Tangga dan Pemenuhan Gizi Seimbang. Temu Ilmiah \& Kongres PERSAGI XIII; 20-24 Nopember 2005; Denpasar, Indonesia.

12. Handajani. Pangan dan Gizi. Edisi pertama. Surakarta: Sebelas Maret University Press; 1994.
13. Ardian, M Irqan, KhairulA. Penelitian Perilaku Keluarga dan Pemenuhan Gizi di Kabupaten Lombok Timur. Mataram: Politeknis Kesehatan Mataram; 2005.

14. Dikes NTB. Laporan Pemantauan Wilayah Setempat (PWS) Program Kesehatan Ibu dan Anak. Mataram: Seksi KIA; 2004.

15. Dinkes NTB. Laporan Penelitian Faktor Penyebab Balita Kurang Energi Protein (KEP). Mataram: Dinas Kesehatan Propinsi NTB-Akademi Gizi Mataram; 2002.

16. Lutter C. Recommended Length of Exclusive Breasfeed, Age of Introduction of Compiementary Foods and the Weaning Dilemma. Woshington DC: Wellstart International; 1992.

17. Dikes NTB. Laporan Hasil Pemantauan Wilayah Setempat (PWS)-KIA 2005. Mataram: Dinas Kesehatan Propinsi NTB; 2005c.

18. Pudjiadi S. Ilmu Gizi Klinis pada Anak. Jakarta: Gayabaru; 1990. 